Çukurova Üniversitesi Mühendislik Fakültesi Dergisi, 36(2), ss. 317-329, Haziran 2021

Cukurova University Journal of the Faculty of Engineering, 36(2), pp. 317-329, June 2021

\title{
The Social and Economic Impacts of Novel Coronavirus Pandemic on Construction Sector and its Professionals
}

\author{
Olcay GENÇ ${ }^{* 1}$ \\ ${ }^{1}$ İskenderun Teknik Üniversitesi, Mühendislik ve Doğa Bilimleri Fakültesi, İnşaat Mühendisliği \\ Bölümü, İskenderun
}

Geliş tarihi: 23.02.2021 Kabul tarihi: 30.06.2021

\begin{abstract}
The goal of this study is, in an unexpected exceptional situation such as Covid-19 outbreak, to demonstrate how the extent of understanding of the situation and its social and economic impact on the construction sector and on its practitioners can be defined and exposed. Hence, to provide insights to the practitioners to prepare the sector and its professionals for the next extraordinary situation. A questionnaire survey is prepared and delivered personally and via the Chamber of Civil Engineers to the civil engineers who work for public or private sectors, and then a comparative analysis is carried out. The exploratory results of the study show that the civil engineers follow precaution rules against Covid-19, they stay home unless compulsory matters, they are highly concerned about global, national and family economies after coronavirus pandemic and, while the majority of the civil engineers somehow continue working during the pandemic, only a very small portion of the private sector companies bankrupt.
\end{abstract}

Keywords: Economy, Construction sector, Coronavirus, Covid-19, Pandemic

\section{Yeni Tip Koronavirüs Salgınının İnşaat Sektörü ve Sektör Profesyonelleri Üzerindeki Sosyal ve Ekonomik Etkileri}

$\ddot{O} z$

Bu çalışmanın amacı, Covid-19 salgını gibi beklenmedik bir durumda, durumun anlaşılma derecesinin ve bunun inşaat sektörü ve uygulayıcıları üzerindeki sosyal ve ekonomik etkisinin nasıl tanımlanıp ortaya çıkarılabileceğini göstermektir. Bu nedenle, sektörü ve profesyonellerini bir sonraki olağanüstü duruma hazırlamak için uygulayıcılara öngörü sağlamaktır. Kamu veya özel sektörde çalışan inşaat mühendislerine anket çalışması hazırlanarak bizzat ve İnşaat Mühendisleri Odası aracılığı ile ulaştırılmakta ve ardından karşılaştırmalı bir analiz yapılmaktadır. Çalışmanın sonuçları, inşaat mühendislerinin Covid-19'a karşı önlem kurallarına uyduğunu, zorunlu olmadıkça evde kaldıklarını, koronavirüs pandemisinden sonra küresel, ulusal ve aile ekonomileri konusunda son derece endișelendiklerini ve inşaat mühendislerinin büyük çoğunluğunun bir şekilde pandemi sırasında çalışmaya devam ettiklerini ve özel sektör şirketlerinin sadece çok küçük bir kısmının iflas ettiğini göstermektedir.

Anahtar Kelimeler: Ekonomi, Covid-19, Koronavirüs, İnşaat sektörü, Pandemi

*Sorumlu yazar (Corresponding author): Olcay GENÇ, olcay.genc@iste.edu.tr 


\section{INTRODUCTION}

Coronaviruses are enveloped un-segmented positive-sense RNA viruses that belong to the Coronaviridae community and are commonly distributed to mammals including humans [1]. While most human coronavirus infections are moderate, the two epidemics, SARS and MERS cause approx. 10,000 cases over the last twenty years, with rates of death of $10 \%$ and $37 \%$, respectively [2,3]. A recent series of reports of pneumonia in Wuhan, China, is caused by a novel beta coronavirus, the Covid-19 (Corona Virus Disease 2019) [4] confirmed by Chinese health officials in January 2020 [5]. On 11 March 2020, the World Health Organization (WHO) announced a pandemic of COVID-19, referring to more than 118.000 cases of coronaviral disease in more than 110 countries and territories across the world and the growing possibility of more global dissemination [6]. The new disease spread throughout almost all countries around the world in three months. As of December 31, 2020, a total of 81.947.503 confirmed Covid-19 cases, including 1.808 .041 deaths $(2.20 \%)$ in 216 countries are reported by the World Health Organization [7]. The novel coronavirus is first diagnosed on 11 March 2020 in Turkey [8]. As of December 31, 2020, a total of 2.220.855 confirmed Covid-19 cases, including 21.093 deaths $(0.94 \%)$ in Turkey is reported by the ministry of health [8]. In the period from the first Covid-19 diagnosis to the present, the activities are canceled, schools are shut, many businesses and shopping malls are closed, curfews are declared for certain age groups and metropolitan cities on certain days in Turkey.

The Covid-19 disease outbreak has alarming effects on human lives as well as the economies of affected countries, i.e., with production hubs around the world undergoing a period of prolonged factory closures, the economic effect transcends national borders through global supply chains [9]. Other than natural disasters and human-made hazards, the world is unprepared to cope with disease outbreaks such as the COVID-19. The construction sector is considered one of the leading and immersive sectors of the economy [10] because of the relationships between the construction sector and the whole economy, as well as the intersectoral relationships between construction and other industries [11]. Governments' use of construction investments as a tool to stabilize the economy also demonstrates the sector's central role in the national growth strategy $[11,12]$, which means if the sector stops, the growth will stop as well, and the economic collapse may start. The literature lacks to have investigations on the social and economic impacts of a pandemic on the construction sector.

The aim of this study is, in an unforeseen extraordinary situation, to show how to define and reveal the perception level of the situation, and its social and economic effects on the construction sectors and its professionals. Hence, to provide insights to the practitioners to prepare the sector and its professionals for the next extraordinary situation. To this end, a questionnaire survey concerning the perception and social and economic effects of the Covid-19 pandemic on the construction sector is prepared and delivered to civil engineers personally and via the Chamber of Civil Engineers. Finally, comparative analyses are carried out by using different methods.

The remainder of this paper is organized as follows. Section 2 presents the materials and methods. Section 3 provides the results of the analysis and also discusses the findings. Finally, Section 4 draws the conclusions.

\section{MATERIALS AND METHODS}

A questionnaire survey is used to solicit views and personal experiences of construction professionals regarding the perception and social and economic effects of the Covid-19 pandemic on the Turkish construction sector. A questionnaire entitled "The Perception of Coronavirus Pandemic on Construction Sector Professionals and the Impacts on the Sector" is prepared and delivered to civil engineers, who work in Turkey, personally and via the Chamber of Civil Engineers. The questionnaire consists of four sections. 
- Section 1: Demographics of participants

- Section 2: Perception level, compliance, and satisfaction with the precaution rules

- Section 3: Satisfaction with the healthcare system

- Section 4: The social and economic effects of the pandemic on the sector and sector professionals, the adequacy of the economic policy steps taken by the government

The sample size of the study is 456 participants, which indicates sufficiency for statistical analysis [13-15]. The reliability of the scales is evaluated by calculating Cronbach's alpha coefficient. The Cronbach's alpha value of 0.7 and above is considered high internal consistency [16].

Parametric tests are used to analyze the data because collected data are always normally distributed. Based on the comparison of the opinions of civil engineers working in the public and private sector, the results are analyzed and evaluated using the Likert scale, frequency analysis, T-Test, Crosstabulation analysis, and Pareto analysis. This Study was approved by Yozgat Bozok University Ethics Committee (No:95799348-050.01.04-E.29925; Date: 25.11 .2020$)$

\subsection{Likert Scale}

To assess attitudes, which are preferred ways of acting/responding in a particular situation rooted in a fairly lasting structure of values and ideas gained through social experiences, the scale is developed in a scientifically agreed and validated manner in 1932 by Likert [17]. In this study, the five-point Likert scale (1- extremely poor to 5-extremely good) is used. Likert scale questions are analyzed by calculating the average score (Equation 1)) and using the evaluation criteria presented in Table 1 $[14,18]$.

$$
\bar{x}=\frac{(a \times 5+b \times 4+c \times 3+d \times 2+e \times 1)}{(a+b+c+d+e)}
$$

where a is the number of respondents who answer "definitely agree"; b is the number of respondents who answer "agree"; $\mathrm{c}$ is the number of respondents who answer "neither agree nor disagree"; $d$ is the number of respondents who answer "disagree"; and $\mathrm{e}$ is the number of respondents who answer "definitely disagree". Please note that negative expressions, e.g., I do not feel-good today, coded in reverse (1- definitely agree to 5- definitely disagree).

Table 1. The evaluation criteria of Likert scale questions

\begin{tabular}{|c|c|}
\hline Score Interval (Mean) & Evaluation Criteria \\
\hline $1,00-1,79$ & Very low level \\
\hline $1,80-2,59$ & Low level \\
\hline $2,60-3,39$ & Medium level \\
\hline $3,40-4,19$ & High level \\
\hline $4,20-5,00$ & Very high level \\
\hline
\end{tabular}

\subsection{Frequency Analysis}

Frequency analysis is a part of descriptive statistics that describes the characteristics of a set of data quantitatively [19]. The frequency indicates the number of times an event occurs in statistics. The analysis is an important area of statistics that works with the number of occurrences (frequency) and analyzes the measurements of central tendency, diffusion, percentiles, etc. [20].

\subsection{T-Test}

A t-test is a form of inferential analysis used to assess if there is a significant difference between the results of two classes that could be linked to certain characteristics [21]. There are two types of t-test: (1) the independent t-test, i.e., the classes under comparison are independent of each other, and (2) the dependent t-test, i.e., the classes under comparison are dependent on each other [22]. This study employs the independent t-test.

\subsection{Cross Tabulation Analysis}

Cross tabulation is a method to analyze the relationships between multiple variables quantitatively by employing frequency distribution of events displayed on a contingency table [13]. The analysis is followed by a chi-square test to assess statistical significance. 


\subsection{Pareto Analysis}

The technique is a formal methodology where several different courses of action are competing for consideration. Pareto analysis is often called the $80 / 20$ rule indicating $20 \%$ of the reasons cause $80 \%$ of the results [23], e.g., $20 \%$ of the risks have the most impact $(80 \%)$ on a project or $20 \%$ of all consumers account for $80 \%$ of all shopping.

\section{RESULTS AND DISCUSSION}

This section presents the results of the analysis. Firstly, the demographics of the participants are presented. This is followed by the results of analysis concerning perception, compliance, and satisfaction with the precaution rules. Then, the results of the analysis concerning trust in government, health officials, and the oppositions, satisfaction with the healthcare system are presented. Finally, the result of the social and economic effects of the pandemic are presented.

\subsection{Demographics of the Participants}

The demographic characteristics of the respondents are presented in Table 2. The gender composition of the sample is $86.18 \%(\mathrm{f}=393)$ male and $13.72 \%$ $(\mathrm{f}=63)$ female. All participants are civil engineers and most of them $(78.29 \%)$ work for the private sector.

Table 2. The demographic composition of the participants

\begin{tabular}{|c|l|c|c|}
\hline \multicolumn{2}{|c|}{ Demographics } & f & $\%$ \\
\hline \multirow{4}{*}{ Gender } & Male & 393 & 86.18 \\
\cline { 2 - 4 } & Female & 63 & 13.72 \\
\cline { 2 - 4 } & Total & 456 & 100 \\
\hline \multirow{4}{*}{ Sector } & Private & 357 & 78.29 \\
\cline { 2 - 4 } & Public & 99 & 21.71 \\
\cline { 2 - 4 } & Total & 456 & 100 \\
\hline \multirow{3}{*}{ Occupation } & Civil Engineer & 456 & 100 \\
\cline { 2 - 4 } & Total & 456 & 100 \\
\hline
\end{tabular}

\subsection{Perception, Compliance and Satisfaction with the Precaution Rules}

Table 3 shows the average scores of participants' compliance with the precaution rules specified by the authorities against Covid-19 and the outcome of the t-test. It is observed from the table that all participants highly agree $(3.40 \leq \bar{x} \leq 4.19)$ with following the precaution rules against novel coronavirus. The variable "worn mask where it is necessary" has the highest average rating of 4.409 while the variable "paid attention to the sleeping pattern" has the lowest average rating $(\bar{x}=3.000)$. Ttest results show that there is statistically significant disagreement $(\mathrm{p} \leq 0.05)$ between public and private sector' civil engineers on all variable averages except for the variable "paid attention to the sleeping pattern". The public sector' mean values of the variables "stayed home except for mandatory situations", "Stopped seeing risky-group relatives", and "Stopped eating outside/from outside" are higher than private-sector' mean values $\bar{x}_{\text {public }}=4.51, \bar{x}_{\text {private }}=4.08 ; \bar{x}_{\text {public }}=4.42, \bar{x}_{\text {private }}=4.06$ $\left(; \bar{x}_{\text {public }} 3.77, \bar{x}_{\text {private }}=3.32\right.$, respectively). Although the other variables' mean values differ by sectors, they fall into the same evaluation criteria category and does not have a difference of interpretation.

The reasons for the participants to leave their homes are presented in Table 4. Figure 1 shows the Pareto diagram of the reasons for going outside. It is evident that $85 \%$ of the reasons for leaving home are based on four basic categories:

- Shopping

- Going to work

- Exercising

- Visiting relatives who in need

When the main reasons for leaving home are examined, except for the exercising, it is seen that the participants go out only in compulsory situations, which is in line with participants' agreement on following the precaution rules specified by the authorities against Covid-19. First of the reasons for leaving home is "shopping", e.g., going to market, with $74.34 \%$ rate $(\mathrm{f}=339)$ followed by "going to work" $(72.36 \%)$ and "for relatives who in need" $(14.47 \%)$. 
Table 3. Compliance with the precaution rules

\begin{tabular}{|c|c|c|c|c|c|c|c|c|c|}
\hline \multirow[t]{2}{*}{ Variables } & \multicolumn{2}{|c|}{$\begin{array}{c}\text { All } \\
\text { participants }\end{array}$} & \multicolumn{6}{|l|}{ t-test } & \multirow[b]{2}{*}{$\begin{array}{l}\text { Cron. } \\
\text { Alpha }\end{array}$} \\
\hline & $\bar{x}$ & $\sigma$ & $\begin{array}{l}\text { EVA/ } \\
\text { EVNA }\end{array}$ & $\mathbf{F}$ & Sig. & $\mathbf{t}$ & df & $\begin{array}{c}\text { Sig. } \\
(2- \\
\text { tailed) } \\
\end{array}$ & \\
\hline \multirow{2}{*}{$\begin{array}{l}\text { Washed hands more } \\
\text { than usual }\end{array}$} & \multirow{2}{*}{4.272} & \multirow{2}{*}{1.176} & EVA & \multirow{2}{*}{11.823} & \multirow{2}{*}{0.001} & -2.636 & 454 & 0.009 & \multirow{20}{*}{0.877} \\
\hline & & & EVNA & & & -3.148 & 212.137 & 0.002 & \\
\hline \multirow{2}{*}{$\begin{array}{l}\text { Watched the news } \\
\text { more than usual }\end{array}$} & \multirow{2}{*}{3.347} & \multirow{2}{*}{1.299} & EVA & \multirow{2}{*}{0.827} & \multirow{2}{*}{0.364} & 1.165 & 454 & 0.245 & \\
\hline & & & EVNA & & & 1.133 & 150.758 & 0.259 & \\
\hline \multirow{2}{*}{$\begin{array}{l}\text { Worn mask where it } \\
\text { is necessary }\end{array}$} & \multirow{2}{*}{4.409} & \multirow{2}{*}{1.046} & EVA & \multirow{2}{*}{9.275} & \multirow{2}{*}{0.002} & -2.453 & 454 & 0.015 & \\
\hline & & & EVNA & & & -2.978 & 219.686 & 0.003 & \\
\hline \multirow{2}{*}{$\begin{array}{l}\text { Stayed home except } \\
\text { for mandatory } \\
\text { situations }\end{array}$} & \multirow[b]{2}{*}{4.179} & \multirow[b]{2}{*}{1.199} & EVA & \multirow[b]{2}{*}{13.182} & \multirow[b]{2}{*}{0.000} & -3.185 & 454 & 0.002 & \\
\hline & & & EVNA & & & -4.130 & 255.463 & 0.000 & \\
\hline \multirow{2}{*}{$\begin{array}{l}\text { Followed social- } \\
\text { distance rule }\end{array}$} & \multirow{2}{*}{4.300} & \multirow{2}{*}{1.012} & EVA & \multirow{2}{*}{7.011} & \multirow{2}{*}{0.008} & -0.370 & 454 & 0.712 & \\
\hline & & & EVNA & & & -0.444 & 214.590 & 0.657 & \\
\hline \multirow{2}{*}{$\begin{array}{l}\text { Stopped seeing } \\
\text { risky-group relatives }\end{array}$} & \multirow{2}{*}{4.145} & \multirow{2}{*}{1.162} & EVA & 1.120 & 0290 & -2.724 & 454 & 0.007 & \\
\hline & & & EVNA & 1.120 & 0.290 & -2.910 & 172.840 & 0.004 & \\
\hline Stopped eating & 4033 & 1296 & EVA & 2549 & 0111 & -0.764 & 454 & 0.445 & \\
\hline outside/from outside & 4.003 & 1.290 & EVNA & 2.549 & 0.111 & -0.804 & 168.878 & 0.422 & \\
\hline Started caring about & 3420 & 1222 & EVA & 9324 & 0007 & -3.257 & 454 & 0.001 & \\
\hline balanced nutrition & 5.420 & $1.2 \angle 2$ & EVNA & 9.324 & 0.002 & -3.480 & 172.879 & 0.001 & \\
\hline Paid attention to the & 3000 & 1304 & EVA & 0007 & 0935 & -1.307 & 454 & 0.192 & \\
\hline sleeping pattern & 5.000 & 1.504 & EVNA & 0.001 & 0.955 & -1.284 & 152.865 & 0.201 & \\
\hline & & & EVA & & & -2.363 & 454 & 0.019 & \\
\hline Mean & 3.90 & 0.853 & EVNA & 0.285 & 0.013 & -2.708 & $\mathbf{1 9 5 . 4 8 7}$ & 0.007 & \\
\hline
\end{tabular}

EVA: Equal variances assumed EVNA: Equal variances not assumed

Table 4. Pareto analysis results of the reasons for leaving home

\begin{tabular}{|c|l|c|c|c|}
\hline No & Reasons & f & cf & \% \\
\hline 1 & Never left home & 36 & 36 & 3.81 \\
\hline 2 & For relatives who in need & 66 & 102 & 10.79 \\
\hline 3 & To use the freedom of going out & 15 & 117 & 12.38 \\
\hline 4 & To exercise & 72 & 189 & 20.00 \\
\hline 5 & Bored & 9 & 198 & 20.95 \\
\hline 6 & To walk my dog & 3 & 201 & 21.27 \\
\hline 7 & To shop (market) & 339 & 540 & 57.14 \\
\hline 8 & To go to work & 330 & 870 & 92.06 \\
\hline 9 & To meet with friends & 15 & 885 & 93.65 \\
\hline 10 & To experience the excitement of breaking the rules & 0 & 885 & 93.65 \\
\hline 11 & To go to a hospital & 60 & 945 & 100.00 \\
\hline 12 & Other & 0 & 945 & 100.00 \\
\hline
\end{tabular}

Note: Because it is a multi-choice question, it can exceed $100 \%$ in total. 


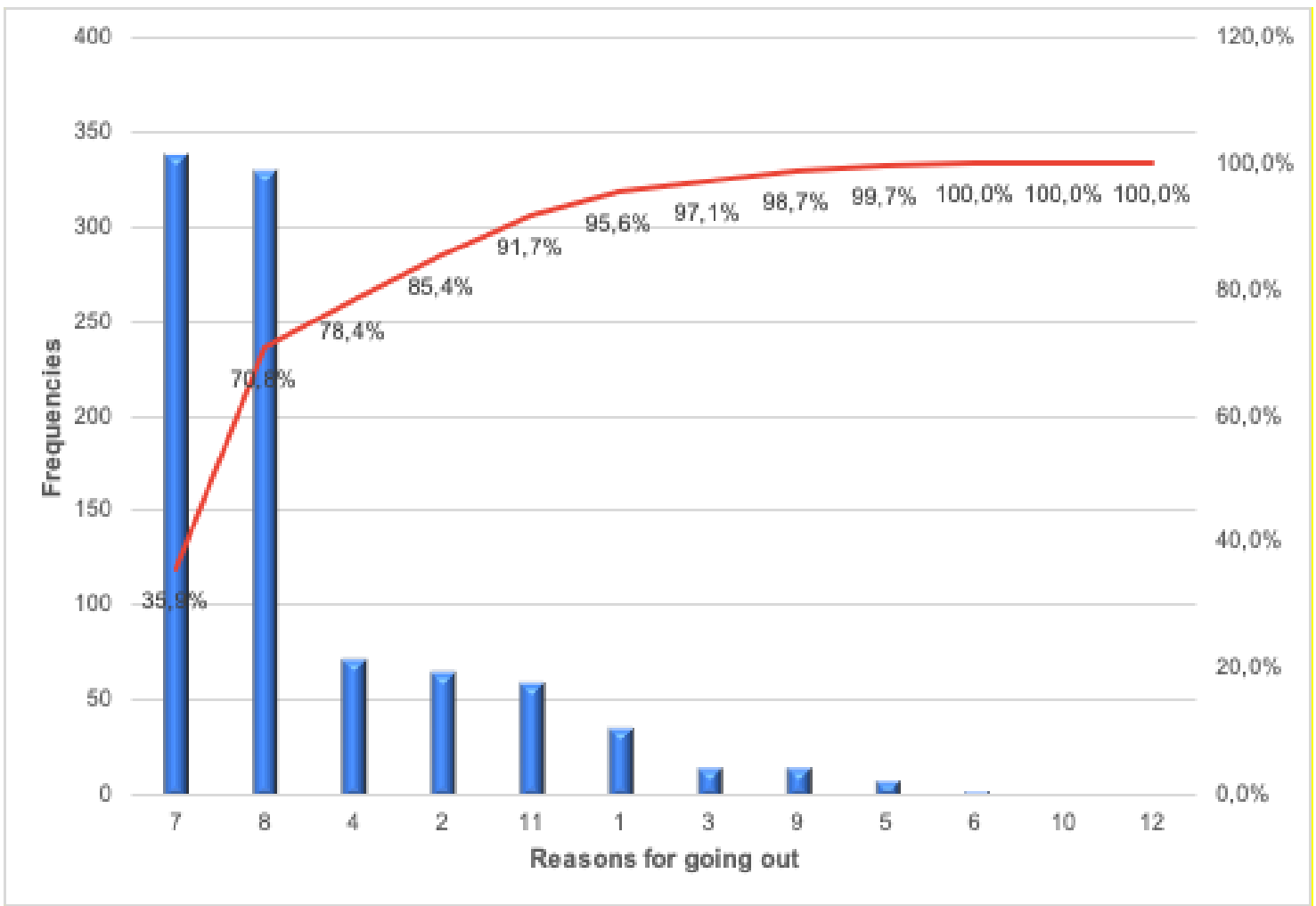

Figure 1. Pareto diagram of the reasons for going outside

Table 5 shows the participants' opinions about the precautions taken by the government against the Covid-19 pandemic. Most of the participants $(60.5 \%$ of the private sector, $51.5 \%$ of the public sector) think that the precautions are not fully sufficient while $0.8 \%$ of the private sector participants think they are excessive. The chisquare test for independence is used to identify associations between the judgments and the survey respondents' sectors. The result shows that there is no difference $(\mathrm{p}>0.05)$ between the sector averages within a $95 \%$ confidence level. In other words, construction professionals agree that the precautions taken by the government are not fair enough.

Table 5. Sector-based contingency table of opinions about precautions

\begin{tabular}{|c|c|c|c|c|}
\hline $\begin{array}{l}\text { Which of the following describes your opinion on the } \\
\text { precautions taken by the government against Covid-19? }\end{array}$ & $\begin{array}{c}\text { Private } \\
(\%)\end{array}$ & $\begin{array}{c}\text { Public } \\
(\%)\end{array}$ & $\begin{array}{c}\text { Total } \\
(\%)\end{array}$ & $\begin{array}{l}\text { Asymp. } \\
\text { Sig. (p) }\end{array}$ \\
\hline The precautions are not fully sufficient & 60.5 & 51.5 & 58.6 & \multirow{6}{*}{0.177} \\
\hline The precautions are appropriate and sufficient & 20.2 & 30.3 & 22.4 & \\
\hline The precautions are not sufficient & 16.8 & 15.2 & 16.4 & \\
\hline The precautions are somewhat excessive & 1.7 & 3.0 & 2.0 & \\
\hline The precautions are excessive & 0.8 & 0.0 & 0.7 & \\
\hline Total & 100 & 100 & 100 & \\
\hline
\end{tabular}


Table 6. Effectiveness of the precautions

\begin{tabular}{|c|c|c|c|c|c|c|c|c|c|}
\hline \multirow[t]{2}{*}{ Variables } & \multicolumn{2}{|c|}{$\begin{array}{c}\text { All } \\
\text { participants }\end{array}$} & \multicolumn{6}{|c|}{ t-test } & \multirow{2}{*}{$\begin{array}{l}\text { Cron. } \\
\text { alpha }\end{array}$} \\
\hline & $\bar{x}$ & $\sigma$ & $\begin{array}{l}\text { EVA/ } \\
\text { EVNA }\end{array}$ & $\mathbf{F}$ & Sig. & $\mathbf{t}$ & df & $\begin{array}{c}\text { Sig. } \\
\text { (2-tailed) }\end{array}$ & \\
\hline \multirow{2}{*}{$\begin{array}{l}\text { The Social-distance method is } \\
\text { effective in preventing the spread of } \\
\text { the virus }\end{array}$} & \multirow{2}{*}{4.395} & \multirow{2}{*}{0.745} & EVA & \multirow{2}{*}{0.763} & \multirow{2}{*}{0.383} & -0.902 & 454 & 0.368 & \multirow{10}{*}{0.712} \\
\hline & & & EVNA & & & -0.983 & 178.759 & 0.327 & \\
\hline \multirow{2}{*}{$\begin{array}{l}\text { Partial curfew is effective in } \\
\text { preventing the spread of the virus }\end{array}$} & \multirow{2}{*}{3.632} & \multirow{2}{*}{1.191} & EVA & \multirow{2}{*}{0.107} & \multirow{2}{*}{0.744} & 1.099 & 454 & 0.272 & \\
\hline & & & EVNA & & & 1.118 & 160.344 & 0.265 & \\
\hline \multirow{2}{*}{$\begin{array}{l}\text { General curfew is effective in } \\
\text { preventing the spread of the virus }\end{array}$} & \multirow{2}{*}{4.493} & \multirow{2}{*}{0.778} & EVA & \multirow{2}{*}{0.499} & \multirow{2}{*}{0.480} & 0.124 & 454 & 0.902 & \\
\hline & & & EVNA & & & 0.119 & 148.197 & 0.906 & \\
\hline \multirow{2}{*}{$\begin{array}{l}\text { Wearing a mask is effective in } \\
\text { preventing the spread of the virus }\end{array}$} & \multirow{2}{*}{4.073} & \multirow{2}{*}{0.947} & EVA & \multirow{2}{*}{5.231} & \multirow{2}{*}{0.023} & 0.870 & 454 & 0.385 & \\
\hline & & & EVNA & & & 0.908 & 166.715 & 0.365 & \\
\hline \multirow{2}{*}{$\begin{array}{l}\text { Washing hands frequently is effective } \\
\text { in preventing the spread of the virus }\end{array}$} & \multirow{2}{*}{4.470} & \multirow{2}{*}{0.657} & EVA & \multirow{2}{*}{0.815} & \multirow{2}{*}{0.367} & -1.809 & 454 & 0.071 & \\
\hline & & & EVNA & & & -1.809 & 156.585 & 0.072 & \\
\hline \multirow{2}{*}{ Mean } & \multirow{2}{*}{4.21} & \multirow{2}{*}{0.603} & EVA & \multirow{2}{*}{0.310} & \multirow{2}{*}{0.578} & 0.123 & 454 & 0.902 & \\
\hline & & & \begin{tabular}{|l|} 
EVNA \\
\end{tabular} & & & 0.120 & 151.842 & 0.905 & \\
\hline
\end{tabular}

EVA: Equal variances assumed EVNA: Equal variances not assumed

The mean values of the participants' opinions about the effectiveness of the precautions specified by the authorities against Covid-19 and also the outcome of the t-test is presented in Table 6. It is seen in the table that participants' agreement on the effectiveness of the precautions is at a very high level $(4.20 \leq \bar{x} \leq 5.00)$. The variable "general curfew is effective in preventing the spread of the virus" has the highest average rating of 4,493 followed by the variables "Washing hands frequently is effective in preventing the spread of the virus" ( $\bar{x}=4.470)$, "Social-distance method is effective in preventing the spread of the virus" $(\bar{x}=4.395)$, "Wearing a mask is effective in preventing the spread of the virus" ( $\bar{x}=4.073)$, and "Partial curfew is effective in preventing the spread of the virus" ( $\bar{x}=3.632)$, respectively. T-test results show that there is no difference $(\mathrm{p}>0.05)$ between the sector's mean values within a $95 \%$ confidence level. This indicates that both public and private sector construction sector professionals find the precautions effective at a very high level.

Table 7. Satisfaction with the healthcare system

\begin{tabular}{|c|c|c|c|c|c|c|c|c|c|}
\hline \multirow[t]{2}{*}{ Variables } & \multicolumn{2}{|c|}{$\begin{array}{c}\text { All } \\
\text { participants }\end{array}$} & \multicolumn{6}{|c|}{ t-test } & \multirow{2}{*}{$\begin{array}{l}\text { Cron. } \\
\text { alpha }\end{array}$} \\
\hline & $\bar{x}$ & $\sigma$ & $\begin{array}{l}\text { EVA/ } \\
\text { EVNA }\end{array}$ & $\mathbf{F}$ & Sig. & $\mathbf{t}$ & df & $\begin{array}{c}\text { Sig. } \\
\text { (2-tailed) }\end{array}$ & \\
\hline \multirow{2}{*}{$\begin{array}{l}\text { Our health infrastructure is sufficient } \\
\text { for the coronavirus pandemic }\end{array}$} & \multirow{2}{*}{3.573} & \multirow{2}{*}{0.9842} & EVA & \multirow{2}{*}{34.509} & \multirow{2}{*}{0.000} & -3.241 & 454 & 0.001 & \multirow{6}{*}{0.881} \\
\hline & & & EVNA & & & -4.735 & 348.107 & 0.000 & \\
\hline \multirow{2}{*}{$\begin{array}{l}\text { Our healthcare professionals are } \\
\text { sufficient for the coronavirus } \\
\text { pandemic }\end{array}$} & \multirow{2}{*}{3.573} & \multirow{2}{*}{0.9842} & EVA & \multirow{2}{*}{-34.509} & \multirow{2}{*}{0.000} & -3.241 & 454 & 0.001 & \\
\hline & & & EVNA & & & -4.735 & 348.107 & 0.000 & \\
\hline \multirow{2}{*}{$\begin{array}{l}\text { I wouldn't want to be in another } \\
\text { country during the Covid-19 } \\
\text { pandemic }\end{array}$} & \multirow[b]{2}{*}{4.173} & \multirow[b]{2}{*}{0.9529} & EVA & \multirow[b]{2}{*}{15.133} & \multirow[b]{2}{*}{0.000} & -1.455 & 454 & 0.146 & \\
\hline & & & EVNA & & & -1.903 & 260.886 & 0.058 & \\
\hline \multirow{2}{*}{ Mean } & \multirow{2}{*}{3.772} & \multirow{2}{*}{0.875} & EVA & \multirow{2}{*}{21.035} & \multirow{2}{*}{0.000} & -2.956 & 454 & 0.003 & \\
\hline & & & EVNA & & & -4.153 & 313.541 & 0.000 & \\
\hline
\end{tabular}

EVA: Equal variances assumed EVNA: Equal variances not assumed 


\subsection{Satisfaction with the Healthcare System}

Table 7 presents the averages of the participants' satisfaction level of the healthcare system of the country. It is observed that participants are highly satisfied with the healthcare system of Turkey $(3.40 \leq \bar{x} \leq 4.19)$. The variable "I wouldn't want to be in another country during coronavirus pandemic" has the highest average rating of 4.173 followed by the variables "Our health infrastructure is sufficient for the coronavirus pandemic" and "Our healthcare professionals is sufficient for the coronavirus pandemic "with the same average ratings $(\bar{x}=3.573$ for both variables $)$. Except for the last variable, t-test results show that there is a difference between the sector averages. However, the averages fall into the same evaluation criteria category and do not have any difference in meaning.

\subsection{Social and Economic Effects}

The averages of participants' anxiety levels are presented in Table 8 . It is observed that participants are between situations, in other words, neither worried nor calm $(2.60 \leq \bar{x} \leq 3.39)$. The variable "generally pessimistic" has the highest average rating of 3.960 indicating that the participants decline to have a pessimist personality. It is followed by the variables "generally optimistic" with a mean value of 3.887 , which is in line with the previous variable's interpretation. The participants are highly concerned about their families' health $(1.80 \leq \bar{x} \leq 2.59)$. T-test results show that there is no difference between the sector's anxiety averages.

Table 8. Anxiety level

\begin{tabular}{|c|c|c|c|c|c|c|c|c|c|}
\hline \multirow[t]{2}{*}{ Variables } & \multicolumn{2}{|c|}{$\begin{array}{c}\text { All } \\
\text { participants }\end{array}$} & \multicolumn{6}{|c|}{ t-test } & \multirow{2}{*}{$\begin{array}{l}\text { Cron. } \\
\text { alpha }\end{array}$} \\
\hline & $\bar{x}$ & $\sigma$ & $\begin{array}{l}\text { EVA/ } \\
\text { EVNA }\end{array}$ & $\mathbf{F}$ & Sig. & $\mathbf{t}$ & df & $\begin{array}{c}\text { Sig. } \\
\text { (2-tailed) }\end{array}$ & \\
\hline \multirow{2}{*}{$\begin{array}{l}\text { Worried because of } \\
\text { the Covid-19 situation }\end{array}$} & \multirow{2}{*}{2.553} & \multirow{2}{*}{1.139} & EVA & \multirow{2}{*}{1.703} & \multirow{2}{*}{0.193} & -0.685 & 454 & 0.494 & \multirow{14}{*}{0.777} \\
\hline & & & EVNA & & & -0.648 & 145.531 & 0.518 & \\
\hline \multirow{2}{*}{ Calm and peaceful } & \multirow{2}{*}{3.100} & \multirow{2}{*}{1.141} & EVA & \multirow{2}{*}{1.781} & \multirow{2}{*}{0.183} & -1.135 & 454 & 0.257 & \\
\hline & & & EVNA & & & -1.090 & 148.396 & 0.277 & \\
\hline \multirow{2}{*}{$\begin{array}{l}\text { Worried about own } \\
\text { health }\end{array}$} & \multirow{2}{*}{2.893} & \multirow{2}{*}{1.237} & EVA & \multirow{2}{*}{7.387} & \multirow{2}{*}{0.007} & 0.161 & 454 & 0.872 & \\
\hline & & & EVNA & & & 0.150 & 142.194 & 0.881 & \\
\hline \multirow{2}{*}{$\begin{array}{l}\text { Worried about family' } \\
\text { health }\end{array}$} & \multirow{2}{*}{2.026} & \multirow{2}{*}{1.070} & EVA & \multirow{2}{*}{4.958} & \multirow{2}{*}{0.026} & 1.225 & 454 & 0.221 & \\
\hline & & & EVNA & & & 1.343 & 180.425 & 0.181 & \\
\hline \multirow{2}{*}{$\begin{array}{l}\text { Stressful because will } \\
\text { have to leave home }\end{array}$} & \multirow{2}{*}{2.873} & \multirow{2}{*}{1.222} & EVA & \multirow{2}{*}{2.809} & \multirow{2}{*}{0.094} & 0.821 & 454 & 0.412 & \\
\hline & & & EVNA & & & 0.806 & 152.564 & 0.422 & \\
\hline \multirow{2}{*}{ Generally pessimistic } & \multirow{2}{*}{3.960} & \multirow{2}{*}{1.039} & EVA & \multirow{2}{*}{0.060} & \multirow{2}{*}{0.807} & 0.892 & 454 & 0.373 & \\
\hline & & & EVNA & & & 0.909 & 160.748 & 0.365 & \\
\hline & & & EVA & & & 0.092 & 454 & 0.926 & \\
\hline & 3.001 & וסל. & EVNA & & 0.300 & 0.091 & 152.859 & 0.928 & \\
\hline & & & EVA & & & 0.284 & 454 & 0.777 & \\
\hline prean & 0.040 & 0.151 & EVNA & 0.119 & 0.017 & 0.258 & 139.390 & 0.796 & \\
\hline
\end{tabular}

EVA: Equal variances assumed EVNA: Equal variances not assumed Note: Except for the second and last variable, the other variables are negative expressions and coded in reverse. 
Table 9. Economic concerns

\begin{tabular}{|c|c|c|c|c|c|c|c|c|c|}
\hline \multirow[t]{2}{*}{ Variables } & \multicolumn{2}{|c|}{$\begin{array}{c}\text { All } \\
\text { participants }\end{array}$} & \multicolumn{6}{|c|}{ t-test } & \multirow{2}{*}{$\begin{array}{l}\text { Cron. } \\
\text { alpha }\end{array}$} \\
\hline & $\bar{x}$ & $\sigma$ & \begin{tabular}{|l|} 
EVA/ \\
EVNA \\
\end{tabular} & $\mathbf{F}$ & Sig. & $\mathbf{t}$ & df & $\begin{array}{c}\text { Sig. } \\
\text { (2-tailed) }\end{array}$ & \\
\hline \multirow{2}{*}{$\begin{array}{l}\text { Economic recession all around } \\
\text { the world after the pandemic }\end{array}$} & \multirow{2}{*}{1.730} & \multirow{2}{*}{0.874} & EVA & \multirow{2}{*}{6.362} & \multirow{2}{*}{0.012} & 0.038 & 454 & 0.969 & \multirow{8}{*}{0.738} \\
\hline & & & \begin{tabular}{|l|} 
EVNA \\
\end{tabular} & & & 0.046 & 213.416 & 0.963 & \\
\hline \multirow{2}{*}{$\begin{array}{l}\text { Economic recession in Turkey } \\
\text { after the pandemic }\end{array}$} & \multirow{2}{*}{1.886} & \multirow{2}{*}{1.017} & EVA & \multirow{2}{*}{.485} & \multirow{2}{*}{0.486} & 0.786 & 454 & 0.432 & \\
\hline & & & EVNA & & & 0.852 & 177.054 & 0.395 & \\
\hline \multirow{2}{*}{$\begin{array}{l}\text { Worried about losing own job } \\
\text { after the pandemic }\end{array}$} & \multirow{2}{*}{3.013} & \multirow{2}{*}{1.257} & EVA & \multirow{2}{*}{18.958} & \multirow{2}{*}{0.000} & -11.173 & 454 & 0.000 & \\
\hline & & & EVNA & & & -13.068 & 203.369 & 0.000 & \\
\hline \multirow{2}{*}{$\begin{array}{l}\text { Worried about a family losing } \\
\text { their job after the pandemic }\end{array}$} & \multirow{2}{*}{2.197} & \multirow{2}{*}{1.113} & EVA & \multirow{2}{*}{19.336} & \multirow{2}{*}{0.000} & -4.855 & 454 & 0.000 & \\
\hline & & & \begin{tabular}{|l|} 
EVNA \\
\end{tabular} & & & -4.177 & 131.316 & 0.000 & \\
\hline \multirow{2}{*}{ Mean } & \multirow{2}{*}{2.206} & \multirow{2}{*}{0.804} & EVA & \multirow{2}{*}{9.709} & \multirow{2}{*}{0.002} & -5.414 & 454 & 0.000 & \\
\hline & & & EVNA & & & -6.416 & 208.795 & 0.000 & \\
\hline
\end{tabular}

EVA: Equal variances assumed EVNA: Equal variances not assumed Note: All variables are negative expressions and coded in reverse.

Table 9 presents the averages of civil engineers' economic concerns after the pandemic. It is seen in the table that civil engineers are highly concerned $(1.80 \leq \bar{x} \leq 2.59)$ about global, national, and family economies after the coronavirus pandemic. The variable "economic recession all around the world after pandemic" has the highest average rating of 1.730 indicating that civil engineers expect an economic crisis all around the world after pandemic at a very high level. It is followed by the variables "economic recession in Turkey after pandemic" with a mean value of 1.886 , "worried about a family losing their job after pandemic" with a mean value of 2.197, and "worried about losing own job after pandemic" with a mean value of 3.013. For the last two variables, t-test results show that there is a difference between the sector averages. The average scores of public sector civil engineers are greater than private-sector averages for the last two variables $\quad\left(\overline{\mathrm{x}}_{\text {public }}=4.12, \overline{\mathrm{x}}_{\text {private }}=2.70 ; \overline{\mathrm{x}}_{\text {public }}=2.66\right.$, $\overline{\mathrm{x}}_{\text {private }}=2.06$, respectively). The reason for the difference for the third variable, which is "worried about losing own job after pandemic", is that the government did not layoff any employee so far and civil engineers' trust in this continue after the pandemic as well.

Figure 2 shows the private sector construction companies' insurance existence for extraordinary situations. Because the question is valid for the only private sector, the public sector's result is not presented. Only $8.40 \%$ of the construction companies have insurance for the economic impact of extraordinary situations like pandemics while 62.20 of them have not. $29.40 \%$ of the participants state that they do not know whether their company has insurance covers inconceivable conditions. This result is in line with the study of Paleari (2019) [24] which indicates that most of the companies tend not to include unforeseen situations effects on their insurance policy because of high insurance penetration rates.

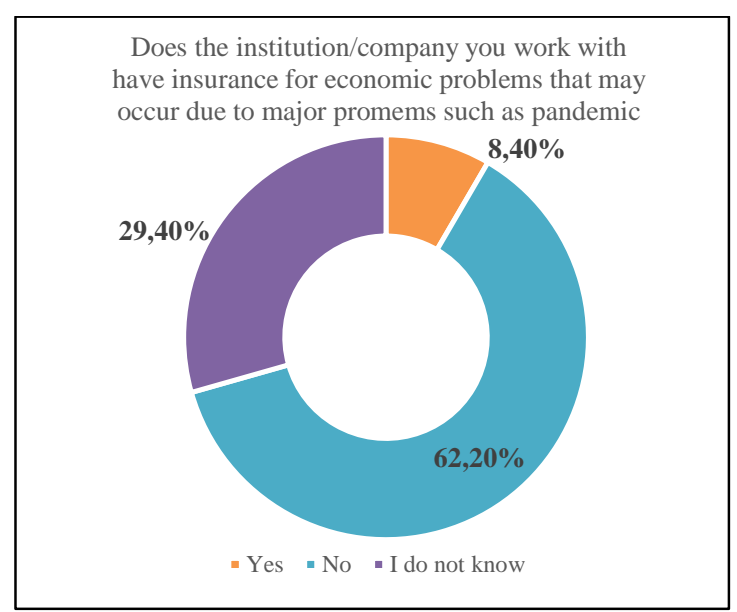

Figure 2. Insurance for the pandemic 
Table 10 presents the effects of the novel coronavirus pandemic on sectors' businesses. When the private sector is examined, it is seen in the table that only $0.9 \%$ of the construction companies have to bankrupt while the majority of them $(70.7 \%)$ have a decrease in their job. The pandemic has not any business effect at all on $27.6 \%$ of the private sector construction companies. When it comes to the public sector, $50.0 \%$ of them have decreased in their jobs while the other $50.0 \%$ has no any changes with their businesses. The result of the chi-square test for independence shows that there is a difference $(\mathrm{p}<0.05)$ between the sector averages within a $95 \%$ confidence level. The reason for the difference is some variables such as "bankrupt" is not valid for the public sector and some variables such as "has decreased in its job" does not affect the sectors equally. Public civil engineers generally control the works of the private sector, and it can be interpreted as the reduction of these inspections cause a decrease in public works.

Table 11 shows the effects of the Covid-19 pandemic on sectors' continued businesses. When the private sector is examined, it is seen in the table that $61.7 \%$ of the construction companies continue their jobs somehow while $22.6 \%$ postpone their holding jobs. A small portion of the private sector construction companies $(15.7 \%)$ cancel the jobs they have when the diseases start. When it comes to the public sector, the majority of the sector $(78.8 \%)$ somehow continue its jobs in hand while $12.1 \%$ postpone their holding jobs, and only a $12.1 \%$ of them cancel the jobs. Although the result of the chi-square test shows that there is a difference $(p<0.05)$ between the sector scores, both the public and private sector put the options in the same order (continued its jobs somehow $>$ had to postpone its jobs $>$ had to leave/cancel its jobs).

Table 10. Effects of the pandemic on sectors' business

\begin{tabular}{|c|c|c|c|c|}
\hline $\begin{array}{l}\text { Because of the Covid-19 pandemic, the company/ } \\
\text { institution being worked for: }\end{array}$ & $\begin{array}{c}\text { Private } \\
(\%)\end{array}$ & $\begin{array}{c}\text { Public } \\
(\%)\end{array}$ & $\begin{array}{c}\text { Total } \\
(\%)\end{array}$ & $\begin{array}{l}\text { Asymp. } \\
\text { Sig. }\end{array}$ \\
\hline Bankrupted & 0.9 & 0 & 0.315 & \multirow{5}{*}{0.000} \\
\hline Had a decrease in its jobs & 70.7 & 50.0 & 66.585 & \\
\hline Had an increase in its jobs & 0.9 & 0.0 & 0.7 & \\
\hline Had no changes & 27.6 & 50.0 & 32.4 & \\
\hline Total & 100 & 100 & 100 & \\
\hline
\end{tabular}

Table 11. Effects of the pandemic on sectors' continued jobs

\begin{tabular}{|l|c|c|c|c|}
\hline $\begin{array}{l}\text { Because of the Covid-19 pandemic, the company/ } \\
\text { institution being worked for: }\end{array}$ & $\begin{array}{c}\text { Private } \\
(\boldsymbol{\%})\end{array}$ & $\begin{array}{c}\text { Public } \\
(\boldsymbol{\%})\end{array}$ & $\begin{array}{c}\text { Total } \\
(\boldsymbol{\%})\end{array}$ & $\begin{array}{c}\text { Asymp. } \\
\text { Sig. }\end{array}$ \\
\hline Had to postpone its jobs & 22.6 & 12.1 & 20.3 & \\
\hline Had to leave/cancel its jobs & 15.7 & 9.1 & 14.2 & \multirow{2}{*}{0.007} \\
\hline Continued its jobs somehow & 61.7 & 78.8 & 65.5 & $\mathbf{1 0 0}$ \\
\hline Total & $\mathbf{1 0 0}$ & $\mathbf{1 0 0}$ & $\mathbf{1 0 0}$ \\
\hline
\end{tabular}

Figure 3 shows the effects of the pandemic on the private sector's employment characteristics. Please note that again, because the question is too valid for the only private sector, the public sector's result is not presented. It is clear that $7.80 \%$ of the construction companies cannot pay the salaries while $12.2 \%$ of them have to decrease the wages. Although $57.40 \%$ of them have no changes with their employment characteristics, $22.6 \%$ of the private sector construction companies have to remove some employees because of the pandemic's negative economic effects on businesses. 


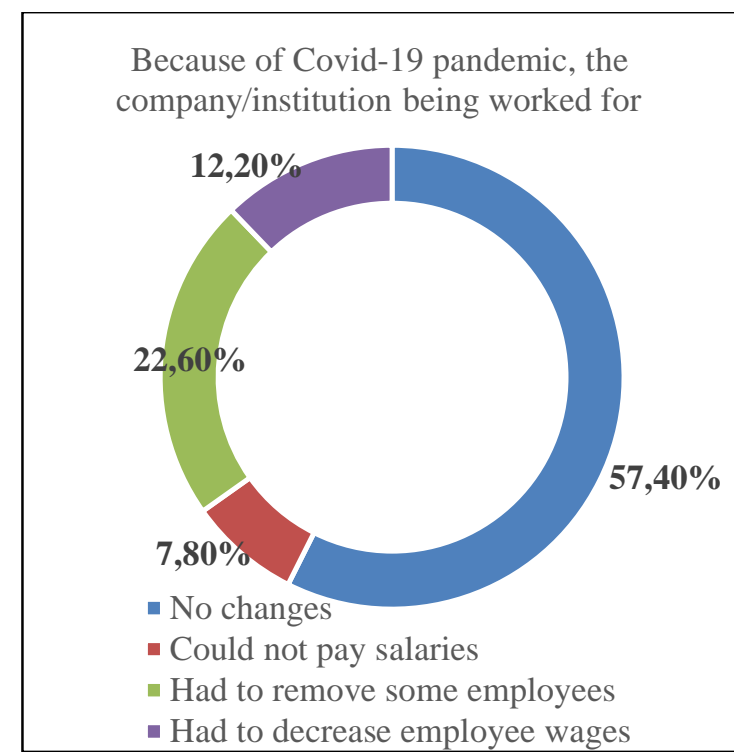

Figure 3. Effects on companies' employment characteristics

The effects of the Covid-19 pandemic on construction sector professionals' employment status are presented in Table $12.8 .0 \%$ of the private sector employees lost their job while this rate is $0.0 \%$ in the public sector. Although $60.0 \%$ of the public and $25.0 \%$ of the private sector' construction professionals work from home with getting the same salary as before the pandemic, $19.6 \%$ of the private sector professionals continue work partially or completely from home with a decrease in their wages. $40.2 \%$ of the private and $40.0 \%$ of the public sector civil engineers continue their job with the same conditions as before the pandemic. However, $4.5 \%$ of the civil engineers who work for the private sector get less salary than before the pandemic although they work their shift the same as before the coronavirus disease. In the private sector, $2.7 \%$ of civil engineers quit their job because of health concerns. The result of the chi-square test for independence shows that there is a difference between the sector averages. The reason for the difference is some variables such as "lost job" are not valid for the public sector and some variables including "wage decrease" do not affect the sectors equally.

Table 12. Effects on employees' employment status

\begin{tabular}{|l|c|c|c|c|}
\hline Because of Covid-19 pandemic: & $\begin{array}{c}\text { Private } \\
(\boldsymbol{\%})\end{array}$ & $\begin{array}{c}\text { Public } \\
(\boldsymbol{\%})\end{array}$ & $\begin{array}{c}\text { Total } \\
(\boldsymbol{\%})\end{array}$ & $\begin{array}{c}\text { Asymp. } \\
\text { sig. }\end{array}$ \\
\hline Lost job & 8.0 & 0.0 & 6.3 & \\
\hline Continued job partially or completely from home without wage changes & 25.0 & 60.0 & 32.4 \\
\hline Continued job partially or completely from home with wage decrease & 19.6 & 0.0 & 14.9 \\
\hline Continued job same way as before the pandemic & 40.2 & 40.0 & 40.7 & \multirow{2}{*}{0.000} \\
\hline Continued job same way as before the pandemic but with wage decrease & 4.5 & 0.0 & 3.5 \\
\hline Resigned because of health concerns & 2.7 & 0.0 & 2.1 \\
\hline Total & $\mathbf{1 0 0}$ & $\mathbf{1 0 0}$ & $\mathbf{1 0 0}$ & \\
\hline
\end{tabular}

Table 13. Effects on own and family

\begin{tabular}{|c|c|c|c|c|}
\hline Caught Covid-19 & Private $(\%)$ & Public (\%) & Total $(\%)$ & Asymp. sig. \\
\hline Yes & 0.8 & 0.0 & 0.7 & \multirow{3}{*}{0.280} \\
\hline No & 97.5 & 100.0 & 99.3 & \\
\hline Total & 100 & 100 & 100 & \\
\hline A relative caught Covid-19 & Private $(\%)$ & Public (\%) & Total $(\%)$ & Asymp. sig. \\
\hline Yes & 8.4 & 18.2 & 10.5 & \multirow{3}{*}{0.005} \\
\hline No & 91.6 & 81.8 & 89.5 & \\
\hline Total & 100 & 100 & 100 & \\
\hline $\begin{array}{l}\text { A relative lost his/her job because of } \\
\text { Covid-19 }\end{array}$ & Private $(\%)$ & Public (\%) & Total $(\%)$ & Asymp. sig. \\
\hline Yes & 31.9 & 30.3 & 32.2 & \multirow{3}{*}{0.617} \\
\hline No & 67.2 & 69.7 & 67.8 & \\
\hline Total & 100 & 100 & 100 & \\
\hline
\end{tabular}


Although most of both public and private sector construction professionals continue working either partially or fully, it is seen in Table 13 that only $0.8 \%$ of the professionals of the private sector diagnosed coronavirus. This indicates that the construction professionals who work for both sectors are very good at following the precaution rules against the pandemic. It is also seen in the table that $18.2 \%$ of the public civil engineers' relatives catch the virus while this ratio is $8.4 \%$ for private sector civil engineers' relatives. The ratio of relatives' job loss is higher in the private sector (31.9\% and $30.3 \%$, respectively) indicating that the private sector' families are affected more than public sector families.

\section{CONCLUSION}

Although the pandemics seen in the last two decades have not a significant impact in the world in terms of health, social and economic, the current pandemic caused by the novel coronavirus (Covid-19) spread to the world in a very short time because of the virus' high transmission rate and caused worldwide damage to these areas that are difficult to repair. Despite arriving late to Turkey, Covid-19 spread all over the country in less than one month. Because of the relationships between the construction sector and the economy as a whole, the sector is considered one of the leading sectors of the economy. Hence, if the sector stops, the economy stops. This study investigates the perception of the Covid-19 pandemic of construction professionals and its social and economic effects on the sector professionals by a questionnaire survey carried out in Turkey. The exploratory results of the study are: (1) although they think precautions are not fully sufficient, the construction professionals tend to follow precaution rules specified by health authorities, (2) they stay home unless compulsory matters, e.g., going to work or market to shop, (3) they trust the government and its institutions about public health, (4) they state that healthcare system of the country is very satisfactory, (5) they are highly concerned about global, national and family economies after coronavirus pandemic, and (6) the majority of the construction professionals somehow continue working and only a very small portion of the private sector companies bankrupt.

The theoretical contribution of this study is in the form of a questionnaire survey study to the construction management knowledge base, in which in an unforeseen extraordinary situation the study illustrates how to define and reveal the perception level of the situation and its social and economic effects on one of the world's leading sectors and its professionals. Considering that there is no such a study addressing these issues, the study provides managerial guidance, to construction industry practitioners to define and cope with the effects of an extraordinary matter such as a pandemic, e.g., anticipating the behavior of sector professionals, taking into account extraordinary situations while regulating the contents of insurance coverage and bilateral employment contracts, etc. Future work will focus on the investigation of opinions of both public and private sector construction firms and their professionals about how to prepare for the next extraordinary situation in terms of social and economic.

The process of collecting data for the questionnaire was carried out in Turkey, and thus it is necessary to endure inter-cultural verification of the tool in order to enhance the generalization of objects. Future studies may replicate the methodology to investigate and compare the outbreak-related risk factors and their outcomes affecting the construction sector in other locations by addressing the limitations.

\section{ACKNOWLEDGMENTS}

My sincere gratitude is extended to the Chamber of Civil Engineers and Fuat KÖKER for their contribution in data collection.

\section{REFERENCES}

1. Richman, D.D., Whitley, R.J., Hayden, F.J., 2016. Clinical Virology, ASM Press, Washington, DC, USA.

2. WHO, 2015. Summary of Probable SARS Cases with Onset of Illness from 1 November 
2002 to 31 July 2003 , https://www.who.int/csr/sars/country/table2004 _04_21/en/ (accessed April 20, 2020).

3. WHO, 2020. Middle East respiratory syndrome coronavirus (MERS-CoV),

https://www.who.int/emergencies/mers-cov/en/ (accessed April 20, 2020).

4. Huang, C., Wang, Y., Li, X., Ren, L., Zhao, J., Hu, Y., Zhang, L., Fan, G., Xu, J., Gu, X., Cheng, Z., Yu, T., Xia, J., Wei, Y., Wu, W., Xie, X., Yin, W., Li, H., Liu, M., Xiao, Y., Gao, H., Guo, L., Xie, J., Wang, G., Jiang, R., Gao, Z., Jin, Q., Wang, J., Cao, B., 2020. Clinical Features of Patients Infected with 2019 Novel Coronavirus in Wuhan, China, Lancet, 497-506.

5. World Health Organization (WHO), 2020. Novel Coronavirus (2019-nCoV) Situation Report - 1, Geneva, Switzerland.

6. Zhang, D., Hu, M., Ji, Q., 2020. Financial Markets Under the Global Pandemic of COVID19, Financ. Res. Lett. 101528.

7. WHO, 2020.

https://www.who.int/emergencies/diseases/nov el-coronavirus-2019 (accessed December 31, 2020).

8. T.C. Sağlık Bakanlığı, 2020. https://www.saglik.gov.tr/ (Accessed December 31, 2020)

9. Yu, K.D.S., Aviso, K.B., 2020. Modelling the Economic Impact and Ripple Effects of Disease Outbreaks, Process Integr. Optim. Sustain.

10. Şafakli, O.V., 2011. An Overview of the Construction Sector in Northern Cyprus, African Journal of Business Management, 5(35), 13383-13387.

11. Giang, D.T.H., Sui Pheng, L., 2011. Role of Construction in Economic Development: Review of Key Concepts in the Past 40 Years, Habitat Int. 35 118-125.

12. Leeper, E.M., Walker, T.B., Yang, S.C.S., 2010. Government Investment and Fiscal Stimulus, J. Monet. Econ. 57, 1000-1012.

13. Erdis, E., Genç, O., Aydınlı, S., 2019. Mobbing on Construction Professionals: Causes, Consequences, and Precautions, Int. J. Constr. Manag.,

14. Çelik, G.T., Oral, E.L., 2016. Big Five and Organizational Commitment-the Case of Turkish Construction Professionals, Hum.
Resour. Manag. Res. 6, 6-14. https://www.semanticscholar.org/paper/Big-

15. Schönbrodt, F.D., Perugini, M., 2013. At What Sample Size do Correlations Stabilize?, J. Res. Pers. 47, 609-612.

16. Mazlina Zaira, M., Hadikusumo, B.H.W., 2017. Structural Equation Model of Integrated Safety Intervention Practices Affecting the Safety Behaviour of Workers in the Construction Industry, Saf. Sci. 98, 124-135.

17. Joshi, A., Kale, S., Chandel, S., Pal, D.K., 2015. Likert Scale: Explored and Explained, Br. J. Appl. Sci. Technol. 7, 396-403.

18. Genç, O., Erdiş, E., Çoşkun, H., 2017. İnşaat Mühendisleri Özelinde Eş Zamanlı Mühendislik Yaklaşımının İrdelenmesi, Çukurova Üniversitesi Mühendislik-Mimarlık Fakültesi Derg. 31, 31-38.

19. Thompson, C.B., 2009. Descriptive Data Analysis, Air Med. J. 28, 56-59.

20. Buchli, J., Righetti, L., Ijspeert, A.J., 2008. Frequency Analysis with Coupled Nonlinear Oscillators, Phys. D Nonlinear Phenom. 237: 1705-1718.

21. Assumpção, A., Pagano, T., Matsutani, L.A., Ferreira, E.A.G., Pereira, C.A.B., Marques, A.P., 2010. Quality of Life and Discriminating Power of Two Questionnaires in Fibromyalgia Patients: Fibromyalgia Impact Questionnaire and Medical Outcomes Study 36-Item ShortForm Health Survey, Brazilian J. Phys. Ther. 14(4), 284-9.

22. Kim, T.K., 2015. T Test as a Parametric Statistic., Korean J. Anesthesiol. 68, 540-6.

23. Hall, R.A., Daneshmend, L.K., 2003. Reliability Modelling of Surface Mining Equipment: Data Gathering and Analysis Methodologies, Int. J. Surf. Mining, Reclam. Environ. 17, 139-155.

24. Paleari, S., 2019. Disaster Risk Insurance: A Comparison of National Schemes in the EU-28, Int. J. Disaster Risk Reduct., 35, 101059. 
